\title{
Synthesis and electrochemistry of linear and cofacial conjugated binuclear phthalocyanines covalently linked by alkyne and alkene bridges
}

\author{
Steven Vigh, Herman Lam, Pavel Janda, A. B. P. Lever, ${ }^{1}$ and Clifford C. Leznoff ${ }^{1}$ \\ Department of Chemistry, York University, North York (Toronto), Ont., Canada M3J 1P3 \\ AND \\ Ronald L. Cerny \\ Midwest Center for Mass Spectrometry, University of Nebraska-Lincoln, Lincoln, NE 68558, U.S.A.
}

\begin{abstract}
Steven Vigh, Herman Lam, Pavel Janda, A. B. P. Lever, Clifford C. Leznoff, and Ronald L. Cerny. Can. J. Chem. 69, 1457 (1991).

Semihydrogenation of 1,2-bis(3,4-dicyanophenyl)ethyne gave cis-1,2-bis(3,4-dicyanophenyl)ethene. From these precursors, binuclear phthalocyanines were produced containing linear binuclear phthalocyanines having an ethyne bridge and a mixture of cis and trans isomers of binuclear phthalocyanines linked by an ethene bridge. The cis and trans isomers could be separated and differentiated by gel permeation chromatography as the very extended trans isomer elutes faster than the cofacial globular cis isomer. Strong coupling between the conjugated binuclear phthalocyanine was not observed when examined by cyclic voltammetry.
\end{abstract}

Key words: phthalocyanines, cofacial, binuclear, cyclic voltammetry.

Steven Vigh, Herman Lam, Pavel Janda, A. B. P. Lever, Clifford C. Leznoff et Ronald L. Cerny. Can. J. Chem. 69, 1457 (1991).

La semi-hydrogénation du 1,2-bis(3,4-dicyanophényl)éthyne conduit au cis-1,2-bis(3,4-dicyanophényl)éthène. À l'aide de ces précurseurs, on a préparé des phthalocyanines binucléaires contenant des phthalocyanines binucléaires linéaires possédant un pont éthyne et un mélange des isomères cis et trans des phtalocyanines binculéaires liées par un pont éthène. On a pu séparé et différencié les isomères cis et trans grâce à la chromatographie à perméation de gel; en effet l'isomère trans, plus étendu, s'élue plus rapidement que l'isomère cis globulaire cofacial. Lorsqu'on les a soumis à de la voltampérométrie cyclique, on n'a pas observé de couplage important entre la phtalocyanine binucléaire conjuguée.

Mots clés : phtalocyanines, cofacial, binucléaire, voltampérométrie cyclique.

[Traduit par la rédaction]

\section{Introduction}

It has been shown (1-4) that binuclear porphyrins, constrained to lie in cofacial configurations, are effective in catalyzing the $4 \mathrm{e}$ reduction of $\mathrm{O}_{2}$ to $\mathrm{H}_{2} \mathrm{O}$. The long-term instability of these porphyrin catalysts, however, has led us to prepare the more stable cofacial binuclear and multinuclear (5-7) phthalocyanines $(8-10)$, having bridges of five $(5,8)$, four $(6)$, three (7), two (6), one (9), zero (7), and even " $(-1)$ " bridges (10). The electrochemistry of some of these cofacial $(7,11)$ and conjugated planar (10) metallophthalocyanines exhibted interesting mixed valence species, but only the $2 \mathrm{e}$ reduction of $\mathrm{O}_{2}$ was observed, albeit with greater efficiency than mononuclear species. We had never attempted to prepare a binuclear phthalocyanine that is both conjugated and cofacial but we have now succeeded in this quest and report its synthesis, and its spectroscopic and electrochemical properties.

\section{Results and discussion}

Synthetic aspects

Semihydrogenation of 1,2-bis(3,4-dicyanophenyl)ethyne (1) (6) in acetonitrile with Lindar's catalyst (12) gave cis1,2-bis( 3,4-dicyanophenyl)ethene (2) in $94 \%$ yield. Treatment of 1 and 2 with gaseous ammonia in a solution of sodium methoxide in methanol $(5,13)$ gave their respective diiminoisoindolines 3 and 4 . Mixed condensation $(5,13)$ of 3 with the diiminoisoindoline (5) (5) derived from 4-neopentoxyphthalonitrile $(5,14)$ gave, upon chromatographic purification using flash (15) and gel permeation chromatography $(8,16), 2,9,16,23-$

\footnotetext{
${ }^{1}$ Authors to whom correspondence may be addressed.

${ }^{2}$ Revision received May 27, 1991.
}

tetraneopentoxyphthalocyanine (6) in $49 \%$ yield and the desired binuclear phthalocyanine (7), linked by an ethyne group in $7.4 \%$ yield (Scheme 1). Binuclear phthalocyanine 7 was readily converted into its diCo(II) derivative (8) by treatment with anhydrous $\mathrm{CoCl}_{2}$ in $77 \%$ yield. Similarly, condensation of 4 and 5 gave mononuclear 6 in $53 \%$ yield and a mixture of the cis and trans binuclear phthalocyanines 9 and 10, linked by ethene groups (Scheme 1). Gel permeation chromatography, using tetrahydrofuran as eluant, succeeded in separating the linear fastmoving trans-binuclear bisphthalocyaninylethene (10) from the slower cofacial cis-binuclear bisphthalocyaninylethene (9). The infrared spectra of 9 and 10 were not characteristically different for these cis and trans isomers and their mass spectral data were identical. Unfortunately, the NMR spectra of 8-10 were uninformative due to their insolubility in appropriate solvents and the fact that these compounds consist of a mixture of 36 regioisomers, with the result that most NMR signals are broad and featureless. Both isomers gave good elemental analysis. These isomers exhibted similar spectral and analytical data but did show mobility differences on gel permeation chromatography. In addition, the major product is the $c i s-9$, the predicted product, while the formation of trans-10 by known facile cis-trans isomerization is understandable. Metallation of 9 with $\mathrm{CoCl}_{2}$ or $\mathrm{Zn}(\mathrm{OAc})_{2}$ gave the $\mathrm{diCo}$ (II) and $\operatorname{diZn}$ (II) derivatives 11 and 12 respectively.

\section{Electronic spectra}

The trans metal-free species $\mathbf{1 0}$ has an electronic spectrum typical of a largely uncoupled mononuclear metal-free phthalocyanine $(5,18)$ while the cis isomer 9 has a blue-shifted $Q$-band spectrum consistent with extensive intramolecular coupling 
<smiles>CC=Nc1ccc(C#Cc2ccc(C#N)c(C#N)c2)cc1C#N</smiles><smiles>C/C=C/c1ccc(C#N)c([13CH2])c1</smiles><smiles>N=C1NC(=N)c2cc(C#Cc3ccc4c(c3)C(=N)NC4=N)ccc21</smiles><smiles>CCc1ccc2c(c1)C(=N)NC2=N</smiles><smiles>[VH3]</smiles>

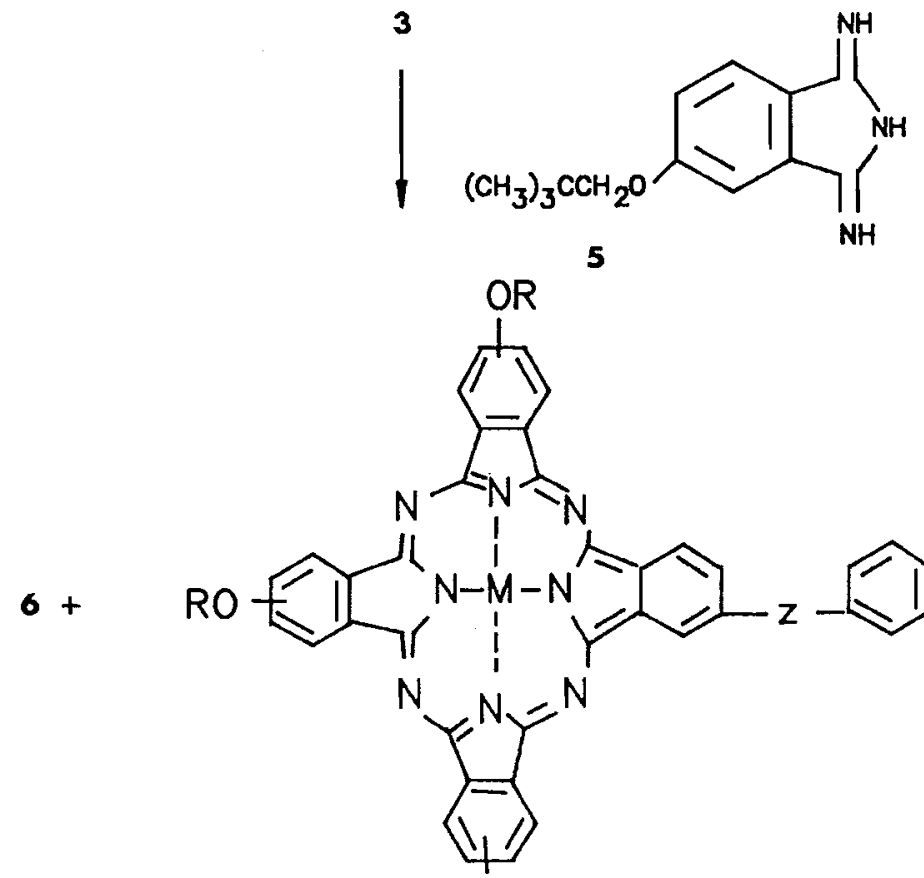<smiles>C=Cc1ccc2c(c1)C(=N)NC2=N</smiles><smiles>CCC</smiles><smiles>[3H][Mg]</smiles>

$$
\begin{array}{ll}
7 \mathrm{Z}=\mathrm{C} \equiv \mathrm{C}, & \mathrm{R}=\mathrm{CH}_{2} \mathrm{C}\left(\mathrm{CH}_{3}\right)_{3} \cdot M=\mathrm{H}_{2} \\
8 \mathrm{Z}=\mathrm{C} \equiv \mathrm{C}, & \mathrm{R}=\mathrm{CH}_{2} \mathrm{C}\left(\mathrm{CH}_{3}\right)_{3} \cdot M=\mathrm{CO} \\
9 \mathrm{Z}=\mathrm{CH}=\mathrm{CH} \text { (cis) }, \mathrm{R}=\mathrm{CH}_{2} \mathrm{C}\left(\mathrm{CH}_{3}\right)_{3} \cdot M=\mathrm{H}_{2}
\end{array}
$$<smiles>[R]Oc1ccc2c(c1)C(=N)N(C)C2=N</smiles>

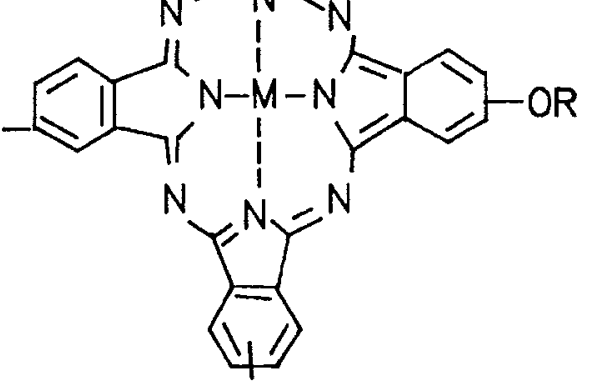

$\mathrm{RO}$

$10 \mathrm{Z}=\mathrm{CH}=\mathrm{CH}$ (trans), $\mathrm{R}=\mathrm{CH}_{2} \mathrm{C}\left(\mathrm{CH}_{3}\right)_{3} \cdot \mathrm{M}=\mathrm{H}_{2}$

$11 \mathrm{Z}=\mathrm{CH}=\mathrm{CH}$ (cis) $, \quad \mathrm{R}=\mathrm{CH}_{2} \mathrm{C}\left(\mathrm{CH}_{3}\right)_{3}, \mathrm{M}=\mathrm{Co}$

$12 \mathrm{Z}=\mathrm{CH}=\mathrm{CH}$ (cis),$\quad \mathrm{R}=\mathrm{CH}_{2} \mathrm{C}\left(\mathrm{CH}_{3}\right)_{3} \cdot \mathrm{M}=\mathrm{Zn}$

SCHEME 1

(18-20). Similar extensive intramolecular coupling is observed in the spectra of the cis dimetallated species 11 and 12, which exhibit typical broad, blue-shifted $Q$-band absorption $(8,11$, $18,19,21,22)$ (Fig. 1). They likely therefore adopt a basically cofacial conformation required by the cis-ethene linkage.

\section{Electrochemistry}

Differential pulse voltammetry (DPV) data for the cobalt complexes 8 and $\mathbf{1 1}$ are reported in Table 1. These complexes are not nearly so well behaved electrochemically as most previously described cobalt phthalocyanine derivatives $(8$, $11,18)$. Although DPV peaks were obtained as listed, the cyclic voltammograms were generally broad and ill-defined, showing a series of overlapping and apparently irreversible waves.

Comparison with the control, CoTNPc (18) species leads to fairly obvious assignments. The ethyne derivative, 8 , has redox processes, as assigned, at potentials almost identical with those of the corresponding mononuclear CoTNPc. No splitting of these waves is noted. The first oxidation is then assigned to the simultaneous oxidation of both rings to the bis- $-\mathrm{Co}{ }^{\mathrm{II}} \mathrm{Pc}(-1)$ 


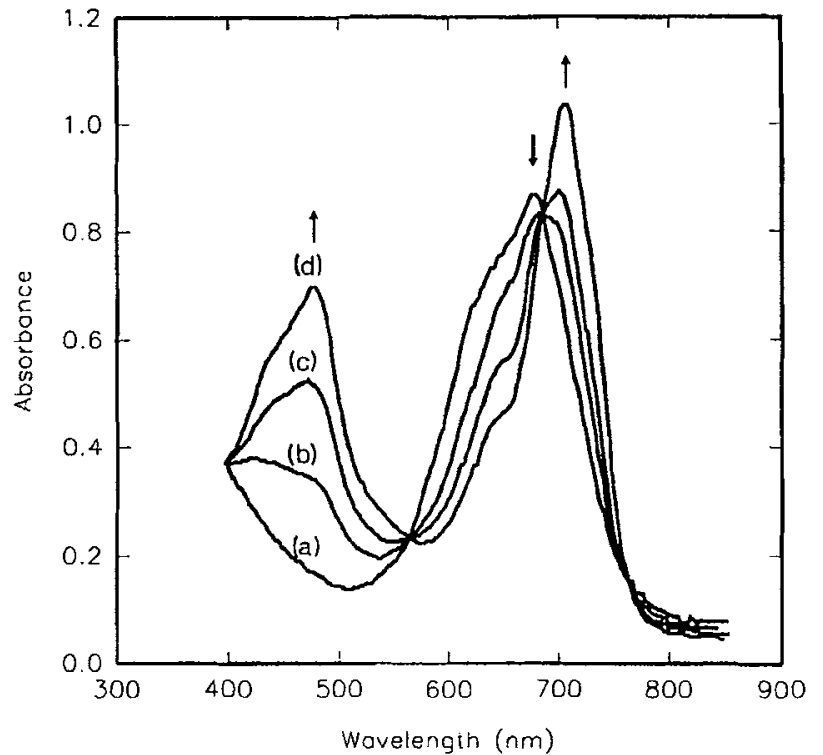

FIG. 1. Spectroelectrochemistry of $\mathrm{CoPc}=\mathrm{PcCo}$ in DCB solution with $0.1 \mathrm{M}$ TBAP, deoxygenated by Ar. Bulk electrolysis at $-1 \mathrm{~V}$ vs. SCE reference electrode. Spectra taken using the Guided Wave fiber optic probe: (a) starting oxidized form $\mathrm{CO}^{\mathrm{II}} \mathrm{Pc}=\mathrm{PcCo}^{\mathrm{II}}$; (d) final reduced form $\mathrm{Co}^{\mathrm{I}} \mathrm{Pc}=\mathrm{PcCo}$. Spectra changed during the bulk electrolysis from (a) to (d) according to arrows.

TABLE 1. Electrochemical data ${ }^{a}$

\begin{tabular}{lcccc}
\hline \hline & \multicolumn{4}{c}{ Process } \\
\cline { 2 - 5 } \multicolumn{1}{c}{ Complex } & I & II & $?$ & IU \\
\hline CoTNPc $^{b}$ & 0.03 & -0.91 & -2.07 & \\
Ethyne 8 & 0.14 & -0.87 & -2.09 & \\
cis-Ethene 11 & 0.13 & -0.91 & -1.52 & -1.80 \\
\hline
\end{tabular}

${ }^{a}$ Differential pulse voltammetry data, $E_{\frac{1}{2}}$ values approximated as the means of the forward and reverse peak positions, in DCB, in volts vs. ferricenium/ferrocene. This couple is observed in these studies at $0.495 \mathrm{~V}$ vs. $\mathrm{AgCl} / \mathrm{Ag}$ on a platinum electrode surface.

${ }^{b}$ Data from ref. 18

radical phthalocyanine species, and reduction involves the simultaneous reduction to the bis- $\mathrm{Co} \mathrm{Pc}(-2)$ species, and then subsequently, at $-2.09 \mathrm{~V}$ (vs. ferrocene), reduction to the bis-ColPc $(-3)$ species.

The cis cobalt ethene complex 11 also shows potentials at roughly those exhibited by CoTNPc but the apparent $\left[\mathrm{Co}{ }^{\mathrm{I} c}(-2)\right]_{2}{ }^{2-} /[\mathrm{Co} \mathrm{Pc}(-3)]_{2}{ }^{4-}$ process is about $0.2 \mathrm{~V}$ more positive than expected. This last observation is reminiscent of the behaviour of recently described napthalene $(11,21)$ and anthracene (11) bridged cobalt phthalocyanines, which show splitting of their $\mathrm{Co}^{\mathrm{II}} / \mathrm{Co}^{\mathrm{I}}$ couples and the formation of mixed valence $\mathrm{Co}^{1 \mathrm{I}} \mathrm{Pc} \cdot \mathrm{Co}{ }^{I} \mathrm{Pc}$ species. Spectroelectrochemical studies (Fig. 1) polarized just negative of this wave (at $-1.0 / \mathrm{V}$ vs. ferrocene) give a spectrum $\lambda_{\max } 475 \mathrm{~nm}$ (MLCT), $708 \mathrm{~nm}(Q$ band) typical of a fully reduced cobalt(I) phthalocyanine species $(5,8,10,11,18,21,22)$, and unlike a mixed valence $\mathrm{Co}^{\mathrm{II}} \mathrm{Pc} \cdot \mathrm{Co}^{\mathrm{I}} \mathrm{Pc}$ binuclear species. The reduction is fully reversible (Fig. 2) since spectroelectrochemical reoxidation regenerated the original spectrum. There is no spectroscopic evidence for a mixed valence intermediate.

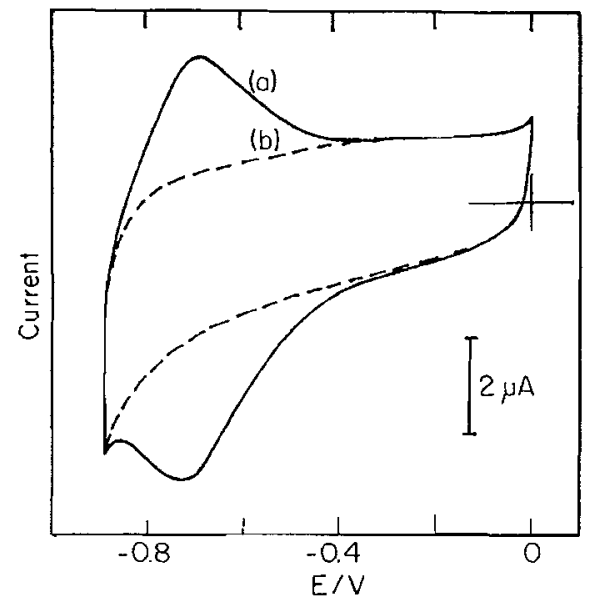

FIG. 2. Cyclic voltammetry of $\mathrm{HOPG} / \mathrm{CoPc}=\mathrm{PcC}$ electrode in aqueous solution of $0.1 \mathrm{M}$ phosphate buffer, $\mathrm{pH}=7, \mathrm{Ar}$, scan rate $v=100 \mathrm{~V} / \mathrm{s}$, potential vs. SCE. (a) $\mathrm{HOPG} / \mathrm{CoPc}=\mathrm{PcCo}$; (b) HOPG (residual current)

We conclude therefore that the interaction between the rings in the ethene derivative $\mathbf{1 1}$ is too small to stablize the mixed valence $\mathrm{Co}^{\mathrm{II}} \mathrm{Pc} \cdot \mathrm{Co}{ }^{\mathrm{I}} \mathrm{Pc}$ species. Moreover, there appears to be an additional redox process at $-1.52 \mathrm{~V}$ (vs. ferrocene). The origin of the $-1.52 \mathrm{~V}$ couple is obscure; it may indeed be due to an impurity process.

\section{Oxygen reduction}

Complexes 8 and 11 were also deposited as monolayer films on highly pyrolytic graphite rotating disk electrodes following methods described earlier (23). These modified electrodes electrocatalyse the reduction of molecular oxygen in a twoelectron process to hydrogen peroxide. No four-electron reduction to oxygen was observed. Since we have extensively discussed the two-electron reduction of oxygen by cobalt phthalocyanines in the past $(11,23)$ no further discussion is presented here.

\section{Experimental}

Matheson high purity argon was used to maintain inert atmosphere conditions. Infrared (ir) spectra were recorded on a Pye Unicam SP1000 infrared spectrophotometer using $\mathrm{KBr}$ discs. Nuclear magnetic resonance $(\mathrm{nmr})$ spectra for protons and carbons were recorded on a Bruker AM300 nmr spectrometer. The position of signals is reported in $\delta$ units. (The splitting of the signals is described as singlets (s), doublets (d), triplets (t), quartets (q), doublets of doublets (dd), or multiplets (m)). The ${ }^{1} \mathrm{H} \mathrm{nmr}$ spectra of $10^{-4} \mathrm{M}$ solutions of the phthalocyanines were obtained by averaging 500-3000 scans over the absorption range. The ultraviolet-visible spectra (uv) were recorded on a Hewlett Packard HP8451A diode array spectrophotometer. Mass spectra (ms) were recorded at $70 \mathrm{eV}$ on a VG Micromass $16 \mathrm{~F}$ mass spectrometer in the EI mode. The FAB spectra were obtained with a Kratos MS-50 triple analyzer mass spectrometer equipped with a FAB ion source of standard Kratos design and Ion Tech atom gun. The sample was dissolved in chloroform and a microlitre of the resulting solution added to a microlitre of $m$-nitrobenzyl alcohol on the probe tip. The spectra of the molecular ions of the binuclear phthalocyanines were obtained by signal averaging up to 256 scans over the approximate mass range. The number in parentheses after the indaicated ion shows the percentage of the base peak represented by that ion. Melting points (mp) were determined using a Kofler hot stage melting point apparatus and are uncorrected. Flash chromatography was performed using silica gel of particle size $20-45 \mu \mathrm{m}$. All reactions were stirred with a magnetic stirrer. All solvents were freshly distilled before use. Thin-layer 
chromatography (tic) was pertormed using stlica gel $G$ as the absorbant. Microanalyses were performed by Guelph Chemical Laboratories Ltd., Guelph, Ontario.

Electrochemical data were obtained with a Princeton Applied Research (PARC) model 173 potentiostat, or a PARC model 174A polarographic analyzer coupled to a PARC model 175 universal programmer. Cyclic voltammetry and differential pulse voltammetry (DPV) were carried out under an atmosphere of argon, or nitrogen, using a conventional three-electrode cell. The working electrode was described by the cross-sectional area of a 27-gauge platinum wire (area $10^{-3} \mathrm{~cm}^{2}$ ), and sealed in glass. A platinum wire also served as the counter electrode. The reference electrode was a silver wire quasireference electrode, referenced intemally to the ferricenium/ferrocene $\left(\mathrm{Fc}^{+} / \mathrm{Fc}\right)$ couple.

Spectroelectrochemical measurements were made with a $0.45-\mathrm{mm}$ path-length optically transparent thin-layer electrode (OTTLE) cell, utilizing a gold minigrid (500 lines/in., 60\% transmittance) (17), in conjunction with the Hitachi Perkin-Elmer model 340 spectrometer.

Preparation of 1,2-bis(3,4-dicyanophenyl)ethylene (1)

Compound 1 was prepared as reported by Marcuccio et al. (6); yield $85 \%, \mathrm{mp} 285-287^{\circ} \mathrm{C}$ (lit. (6) $\mathrm{mp} 286-288^{\circ} \mathrm{C}$ ); ${ }^{1} \mathrm{H}$ nmr (DMSO- $d_{6}, 300$ $\mathrm{MHz}) \delta: 8.42(\mathrm{~d}, J=1.6 \mathrm{~Hz}, 2 \mathrm{H}, \operatorname{Ar} H-3), 8.22(\mathrm{~d}, J=8 \mathrm{~Hz}, 2 \mathrm{H}$ ArH-6), 8.11 (d, $J=8 \mathrm{~Hz}, 2 \mathrm{H}, \mathrm{Ar} H-5$ ).

Preparation of 1,2-bis(3,4-dicyanophentl)ethene (2)

A solution of $1.0 \mathrm{~g}(3.6 \mathrm{mmol})$ of pure 1 in $300 \mathrm{~mL}$ of acetonitrile was stirred under hydrogen $\left(1 \mathrm{~atm}(101.3 \mathrm{kPa}), 25^{\circ} \mathrm{C}\right.$ ) in the presence of Lindlar's catalyst (12) $(250 \mathrm{mg})$ until absorption of hydrogen $(88 \mathrm{~mL})$ had ceased. The catalyst was filtered and the filtrate was evaporated to give $0.950 \mathrm{~g}$ (94\% yield) of a yellow powder 2 . Recrystallization in methanol yielded white, needle-like crystals, mp $196-197^{\circ} \mathrm{C}$; ir $\left(\mathrm{cm}^{-1}\right): 3090-2920,2210(\mathrm{CN}), 1590,1550,1490$ $1380,1230,920,870,850,810,770,720 ;$ uv $\left(\mathrm{CH}_{3} \mathrm{CN}\right) \lambda_{\max }(\log \mathrm{E})$ : 308 (4.09), $276(4.07), 224(4.38) ;{ }^{1} \mathrm{H} \mathrm{nmr}$ (DMSO-d, $\left.300 \mathrm{MHz}\right) \delta$ : $8.00(\mathrm{~s}, 2 \mathrm{H}, \mathrm{Ar} H-3), 7.98(\mathrm{~d}, J=8 \mathrm{~Hz}, 4 \mathrm{H}, \operatorname{Ar} H-6), 7.61(\mathrm{~d}, J=$ $8 \mathrm{~Hz}, 2 \mathrm{H}, \mathrm{Ar} H-5), 6.95(\mathrm{~s}, 2 \mathrm{H}, \mathrm{CH}=\mathrm{CH}) ;{ }^{13} \mathrm{C} \mathrm{nmr} \delta: 141.2(\mathrm{C}-4)$, $134.1+134.0(\mathrm{C}-5+\mathrm{C}-9), 133.6(\mathrm{C}-3), 131.0(\mathrm{C}-6), 115.8+115.6$ $(\mathrm{C}-7+\mathrm{C}-8), 115.1(\mathrm{C}-2), 113.3(\mathrm{C}-1) ; \mathrm{ms} m / z: 280\left(\mathrm{M}^{+}\right), 254$. Anal.

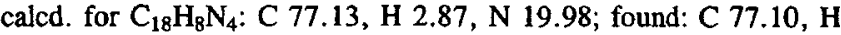
$3.21, \mathrm{~N} 20.17$.

Preparation of the bis-1,3-diiminoisoindoline of 1,2-bis(3,4-dicyanophenyl)ethyne ( 3 )

The bisphthalonitrile $1,0.30 \mathrm{~g}(1.08 \mathrm{mmol})$, was added to a solution of $30 \mathrm{mg}$ of sodium in $30 \mathrm{~mL}$ of dry methanol. Since the bisphthalonitrile 1 did not dissolve, the mixture was heated to $60^{\circ} \mathrm{C}$. The mixture was stirred at $60^{\circ} \mathrm{C}$ for $0.75 \mathrm{~h}$ under reflux conditions, while ammonia gas was bubbed into the solution. The reaction mixture gradually turned green during which time a green precipitate was observed. The reaction was cooled to room temperature and the addition of ammonia gas was discontinued. Evaporation of the solvent gave crude 3, which was used directly in condensation reactions without further purification. Compound 3 did not exhibit a nitrile absorption in its ir spectrum.

Preparation of the bis-1,3-diiminoisoindole of 1,2-bis(3,4-dicyanophenyl)ethene (4)

The bisphthalonitrile $2,0.300 \mathrm{~g}(1.07 \mathrm{mmol})$, was added to a solution of $30 \mathrm{mg}$ of sodium in $30 \mathrm{~mL}$ of dry methanol. The mixture was stirred at room temperature for $0.75 \mathrm{~h}$ while ammonia gas was bubbled into the solution. The reaction mixture gradually became green, during which time a green precipitate was observed. The addition of ammonia gas was discontinued. Evaporation of the solvent gave crude 4, which was used directly in condensation reactions without further purification. Compound $\mathbf{4}$ did not exhibit a nitrile absorption in its ir spectrum.

Preparation of the 1,2-bis-2' $-\left(9^{\prime}, 16^{\prime}, 23^{\prime}\right.$-trineopentoxyphthalocyaninyl)ethyne (7)

The two crude diiminoisoindolines 5 and 3 , obtained from

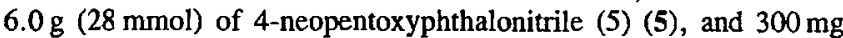
$\left(1.08 \mathrm{mmol}\right.$ ) of 1 , were heated to $150^{\circ} \mathrm{C}$ (oil bath) in $30 \mathrm{~mL}$ of
$2-N, N$-dimethylaminoethanol for $72 \mathrm{~h}$ under an argon atmosphere. The mixture was cooled to room temperature, diluted with water, filtered, and washed thoroughly with water followed by methanol until the filtrate was almost clear. The crude product was extracted with methanol in a Soxhlet apparatus until the extract was clear of brown and yellow impurities. The crude product was purified by flash chromatography using a $5 \mathrm{~cm}$ diameter column packed with flash silica gel $12 \mathrm{~cm}$ high. The crude product was preabsorbed on a small amount of flash silica gel and eluted with toluene to give $300 \mathrm{~g}$ of the monomeric $2,9,16,23$-tetraneopentoxyphthalocyanine (6) in $49 \%$ yield. Further elution with 2-methoxyethanol/toluene (2:98) gave a fraction consisting largely of dimer 7 , containing traces of monomer and some green material. Finally, elution with 2 -methoxyethanol/toluene (1:4) gave a green fraction consisting largely of trimer and impurities. The dimer fraction was further purified by gel permeation chromatography ( 8 , 16). Elution wih tetrahydrofuran removed all traces of monomer and green material from the major dimer band. Evaporation of the solvent gave a dark blue product. This product was washed with acetonitrile/ acetone to remove traces of fluorescent impurities, detectable by tlc using toluene/2-methoxyethanol $(98: 2)$ as eluant to give, in $7.4 \%$ yield, $125 \mathrm{mg}$ of 7 as a dark blue, shiny solid; ir $\left(\mathrm{cm}^{-1}\right): 3300(\mathrm{~N}-\mathrm{H})$, $1610,1480,1400,1240,1100,1020(\mathrm{~N}-\mathrm{H}), 750$; uv (o-dichlorobenzene (DCB)) $\lambda_{\max }(\log \varepsilon): 678$ (4.36), 660 (4.39), 648 (4.45); ms $m / z: 1569.8(23), 1568.8(58), 1567.8\left(\mathrm{M}^{+}+1,100\right), 1566.8\left(\mathrm{M}^{+}\right.$, 86). Anal. calcd. for $\mathrm{C}_{96} \mathrm{H}_{94} \mathrm{~N}_{16} \mathrm{O}_{6}: \mathrm{C} 73.54, \mathrm{H} \mathrm{6.04}, \mathrm{N}$ 14.29; found: C 73.30, H 5.95, N 13.94 .

Preparation of $1,2-$ bis-2' $-\left(9^{\prime}, 16^{\prime}, 23^{\prime}\right.$-trineopentoxyphthalocyaninyl)ethyne dicobalt $(I I)(8)$

A mixture of $50 \mathrm{mg}(0.032 \mathrm{mmol})$ of metal-free dimer 7 and $100 \mathrm{mg}$ $(0.77 \mathrm{mmol})$ of anhydrous cobalt(II) dichloride in $10 \mathrm{~mL}$ of a $1: 1$ mixture of 2-methoxyethanol/dichlorobenzene was heated at $16^{\circ} \mathrm{C}$ for $20 \mathrm{~h}$ under an argon atmosphere. The crude reaction mixture, after cooling, was evaporated under high vacuum to remove the 2-methoxyethanol/dichlorobenzene. The remaining residue was precipitated with a water/methanol (1:1) mixture. After filtering, the dark blue, shiny solid obtained was extracted with methanol in a Soxhlet apparatus until the extract was clear. The dark blue solid was dried to give $41 \mathrm{mg}$ ( $76 \%$ yield) of 8 ; ir $\left(\mathrm{cm}^{-1}\right): 1620,1530,1480,1410,1380,1240,1100$, 760; uv (DCB) $\lambda_{\max }(\log$ E): $686(4.21), 658$ (4.23), 650 (4.19), 638 (4.18), $630(4.19), 302$ (4.33), $262(4.04) ; \mathrm{ms} \mathrm{m} / z: 1683.6$ (23), 1682.6(58), 1681.6(M $\left.\mathrm{M}^{+}+1,100\right), 1680.6\left(\mathrm{M}^{+}, 86\right)$. Anal. calcd. for $\mathrm{C}_{96} \mathrm{H}_{90} \mathrm{~N}_{16} \mathrm{O}_{6} \mathrm{Co}_{2}$ : C 68.56, H 5.39, N 13.39, Co 7.01; found: $\mathrm{C}$ $67.82, \mathrm{H} 5.68, \mathrm{~N} 12.99$, Co 6.80 .

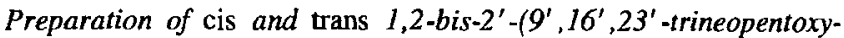
phthalocyaninyl)ethene ( 9 and 10 )

The two crude diiminoisoindolines, 5 and 4 , obtained from $6.0 \mathrm{~g}$ (28 mmol) of 4-neopentoxyphthalonitrile (5) and $300 \mathrm{mg}(1.07 \mathrm{mmol})$ of 2 , were heated to $150^{\circ} \mathrm{C}$ (oil bath) in $30 \mathrm{~mL}$ of $2-N, N$-dimethylaminoethanol for $72 \mathrm{~h}$ under an argon atmosphere. The mixture was cooled to room temperature, diluted with water, filtered, and washed thoroughly with water followed by methanol until the filtrate was almost clear. The crude product was extracted with methanol in a Soxhlet apparatus until the extract was clear of brown and yellow impurities. The crude product was purified by flash chromatography using a $5 \mathrm{~cm}$ diameter column packed with flash silica gel $12 \mathrm{~cm}$ high. The crude product was preabsorbed on a small amount of flash silica gel and eluted with toluene/hexane $(1: 1)$ to give $3.2 \mathrm{~g}$ of the monomeric 6 in $53 \%$ yield. Further elution with toluene gave a fraction consisting largely of dimer and monomer. Finally, elution with 2-methoxyethanol/ toluene (2:98) gave a green fraction consisting largely of trimer and impurities. The dimer fraction was further purified by flash chromatography ( $3 \mathrm{~cm}$ diameter column). Elution with toluene/hexane (25:75) up to $100 \%$ toluene gave an even purer fraction of dimer with a small trace of monomer. This dimer fraction was further purified by gel permeation chromatography $(8,16)$ applying no more than $50 \mathrm{mg}$ of dimer per chromatographic run. Elution with tetrahydrofuran removed all traces of monomer. The main dimer band of 9 was observed but a frontrunning blue band consisting of $\mathbf{1 0}$ was also noticed. These two 
fractions were collected separately. Evaporation of the solvent gave $470.3 \mathrm{mg}$ of 9 and 10 (28\% yield, $378 \mathrm{mg}$ of 9 and $92.3 \mathrm{mg}$ of 10 ) as dark blue solids, having identical ir and $\mathrm{ms}$ spectroscopic properties; ir $\left(\mathrm{cm}^{-1}\right): 3300(\mathrm{~N}-\mathrm{H}), 1620,1480,1400,1240,1100,10.20(\mathrm{~N}-\mathrm{H})$, 750; uv for 9 (DCB) $\lambda_{\max }(\log \varepsilon)$ : 704 (5.06), 650 (5.00), 344 (5.08); uv for $10 \lambda_{\max }(\log \varepsilon): 704$ (4.76), 678 (4.77), $658(4.78), 650(4.77)$, $340(4.86) ; \mathrm{ms} m / z: 1571.7(23), 1570.7(58), 1569.7\left(\mathrm{M}^{+}+1,100\right)$, $1568.7\left(\mathrm{M}^{+}, 86\right)$. Anal. calcd. for $\mathrm{C}_{96} \mathrm{H}_{90} \mathrm{~N}_{16} \mathrm{O}_{6} \mathrm{Co}_{6}$ for 9: $\mathrm{C} 73.44, \mathrm{H}$ 6.16, N 14.27; found: C 73.51, H 6.52, N 14.24. Anal. calcd. $\mathrm{C}_{96} \mathrm{H}_{96} \mathrm{~N}_{16} \mathrm{O}_{6}$ for 10: $\mathrm{C} 73.44, \mathrm{H} 6.16, \mathrm{~N} 14.27$; found: $\mathrm{C} 73.85, \mathrm{H}$ $6.39, \mathrm{~N} 14.55$.

Preparation of the 1,2-bis-2' $-\left(9^{\prime}, 16^{\prime}, 23^{\prime}\right.$-trineopentoxyphthalocyaninyl)ethyne dicobalt(II) (II)

A mixture of $50 \mathrm{mg}(0.032 \mathrm{mmol})$ of metal-free dimer (9) and $100 \mathrm{mg}(0.77 \mathrm{mmol})$ of anhydrous cobalt(II) dichloride in $13 \mathrm{~mL}$ of a 5:3:5 mixture of 2-methoxyethanol/dichlorobenzene/toluene was heated at $160^{\circ} \mathrm{C}$ for $20 \mathrm{~h}$ under an argon atmosphere. Flash chromatography of the crude reaction mixture on a $3 \mathrm{~cm}$ diameter column of flash silica gel and elution with dimethylformamide (DMF) gave, in $78.5 \%$ yield, $42.2 \mathrm{mg}$ of 11 as a dark blue solid; ir $\left(\mathrm{cm}^{-1}\right): 1615,1480,1400$, $1240,1100,1015,755$; uv (DCB) $\lambda_{\max }(\log \varepsilon): 682(4.82), 650(4.76)$, $300(4.91) ; \mathrm{ms} m / z: 1685.6(23), 1684.6(58), 1683.6\left(\mathrm{M}^{+}+1,100\right)$, 1682.6 $\left(\mathrm{M}^{+}, 86\right)$. Anal. calcd. for $\mathrm{C}_{96} \mathrm{H}_{92} \mathrm{~N}_{16} \mathrm{O}_{6} \mathrm{Co}_{2}: \mathrm{C} 68.48, \mathrm{H}$ 5.50, N 13.31, Co 7.00; found: C 68.71, H 5.85, N 13.54, Co 6.50.

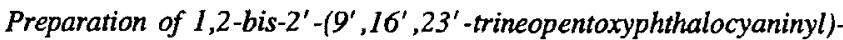
ethene dizinc (II) (12)

A mixture of $60 \mathrm{mg}(0.038 \mathrm{mmol})$ of metal-free dimer 9 and $100 \mathrm{mg}$ $(0.54 \mathrm{mmol})$ of anhydrous zinc acetate in $13 \mathrm{~mL}$ of a 5:3:5 mixture of 2-methoxyethanol/dichlorobenzene/toluene was heated at $160^{\circ} \mathrm{C}$ for $20 \mathrm{~h}$ under an argon atmosphere. Flash chromatography of the crude reaction mixture on a $3 \mathrm{~cm}$ diameter column of flash silica gel and elution with 2-methoxyethanol/toluene (1:3) gave, in $89 \%$ yield, $57.7 \mathrm{mg}$ of 12 as a dark blue solid; ir $\left(\mathrm{cm}^{-1}\right): 1610,1490,1395,1340$, $1235,1100,1060,1015,750$; uv (DCB) $\lambda_{\max }(\log \varepsilon): 688$ (4.99), 658 (4.91), 650 (4.88), 342 (4.99), 300 (4.85); ms $m / z: 1701.6(18)$, $1700.6(31), 1699.6(46), 1698.6(68), 1697.6(84), 1696.6(100)$, $1695.6(82), 1694.6(85), 1693.6\left(\mathrm{M}^{+}+1,54\right), 1692.6\left(\mathrm{M}^{+}, 47\right)$. Anal. calcd. for $\mathrm{C}_{96} \mathrm{H}_{92} \mathrm{~N}_{16} \mathrm{O}_{6} \mathrm{Zn}_{2}$ : C 67.96, H 5.46, N 13.20, $\mathrm{Zn} 7.70$; found: C 67.53, H 5.40, N 13.03, $\mathrm{Zn} 7.22$.

\section{Acknowledgements}

Financial support by the Natural Sciences and Engineering Research Council of Canada and by The Office of Naval Research (Washington) is gratefully acknowledged. The work was also funded by the Midwest Center for Mass Spectrometry, a National Science Foundation Regional Instrumentation Facility (Grant No, CHE8620177).

1. J. P. Collman, P. Denisevich, Y. Konai, M. Marrocco, C. Koval, and F. C. Anson. J. Am. Chem. Soc. 102, 6027 (1980); J. P. Collman, F. C. Anson, S. Bencosme, A. Chong, T. Collins, P. Denisevich, E. Evitt, T. Geiger, J. A. Ibers, G. Jameson, Y. Konal, C. Koval, K. Meier, P. OAKLey, R. B. PetTman, E. Schmirtou, and J. Sessler. In Organic synthesis today and tomorrow. Edited by B. M. Trost and C. R. Hutchinson. Pergamon, Oxford. 1981.

2. R. R. Durand, C. S. Benscome, J. P. Collman, and F. C.
Anson. J. Am. Chem. Soc. 105, 2710 (1983); J. P. Collman, F. C. Anson, C. E. Barnes, C. S. Benscome, T. Geiger, E. R. Evitt, R. P. Kreh, K. Meier, and R. B. Pettman. J. Am. Chem. Soc. 105, 2694 (1983).

3. C. K. Chang and I. Abdalmuhdi. J. Org. Chem. 48, 5388 (1983); C. K. Chang, H. Y. Liu, and I. Abdalmuhdi. J. Am. Chem. Soc. 106, 2725 (1984); C. K. Chang and I. AbDalmuhdi. Angew. Chem. 23, 164 (1984); H. Y. LiU, I. AbDalmuHDI, C. K. Chang, and F. C. Anson. J. Phys. Chem. 89, 665 (1985).

4. J. P. Fillers, K. G. Ravichandran, I. Abdalmuhdi, A. Tulinsky, and C. K. Chang. J. Am. Chem. Soc. 108, 417 (1986).

5. C. C. Leznoff, S. M. Marcuccio, S. Greenderg, A. B. P. Lever, and K. B. Tomer. Can. J. Chem. 63, 623 (1985).

6. S. M. Marcuccio, P. I. Svirskaya, S. Greenberg, A. B. P. Lever, C. C. Leznoff, and K. B. Tomer. Can. J. Chem. 63, 3057 (1985).

7. H. LAM, S. M. Marcuccio, P. I. Svirskaya, S. GReEnberg, A. B. P. Lever, C. C. Leznoff, and R. L. Cerny. Can. J. Chem. 67, 1087 (1989); C. C. LezNOFF, H. LAM, W. A. Nevin, N. Kobayashi, P. Janda, and A. B. P. Lever. Angew. Chem. Int. Ed. Engl. 26, 1021 (1987).

8. W. A. Nevin, W. Liu, S. Greenterg, M. R. Hempstead, S. M. Marcuccio, M. Melnik, C. C. LezNoff, and A. B. P. Lever. Inorg. Chem. 26, 891 (1987).

9. S. GreenberG, S. M. Marcuccio, C. C. Leznoff, and K. B. TOMER. Synthesis, 406 (1986).

10. C. C. Leznoff, H. Lam, S. M. Marcuccio, W. A. Nevin, P. Janda, N. Kobayashi, and A. B. P. Lever. J. Chem. Soc. Chem. Commun. 699 (1987).

11. N. Kobayashi, H. Lam, W. A. Nevin, P. Janda, C. C. LEZNOFF, and A. B. P. Lever. Inorg. Chem. 29, 3415 (1990).

12. H. Lindlar. Helv. Chim. Acta, 35, 446 (1952); E. N. Marvell and T. LI. Syntheses, 457 (1973).

13. P. J. Brach, S. J. Grammatica, O. A. Ossanna, and L. Weinberger. J. Heterocycl. Chem. 7, 1403 (1970).

14. W. R. Barger, A. W. SNow, H. Wohltjen, and N. J. Thomas. Thin Solid Films, 132, 113 (1985).

15. W. C. Still, M. Khan, and A. Mitra. J. Org. Chem. 43, 2923 (1978).

16. J. A. Anton, J. Kwong, and P. A. Loach. J. Heterocycl. Chem. 13, 717 (1976).

17. W. A. Nevin and A. B. P. Lever. Anal. Chem. 60, 727 (1988).

18. W. A. Nevin, M. R. Hempstead, W Liu, C. C. Leznoff, and A. B. P. Lever. Inorg. Chem. 26, 570 (1987).

19. W. A. Nevin, W. Liu, and A. B. P. Lever. Can. J. Chem. 65, 855 (1986).

20. E. S. Donsworth, A. B. P. Lever, P. Seymour, and C. C. Leznoff. J. Phys. Chem. 89, 339 (1985).

21. W. Liu, M. R. Hempstead, W. A. Nevin, M. Melnik, A. B. P. Lever, and C. C. Leznoff. J. Chem. Soc. Dalton Trans. 2511 (1987).

22. C. C. Leznoff, H. Lam, W. A. Nevin, N. Kobayashi, P. JANDA, and A. B. P. LeVer. Angew. Chem. Int. Ed. Engl. 26, 1021 (1987).

23. M. R. Hempstead, A. B. P. Lever, and C. C. Leznoff. Can. J. Chem. 65, 2677 (1987); P. JANDA, N. Kobayashi, P. AshbuRn, H. LAM, C. C. LeznofF, and A. B. P. Lever. Can. J. Chem. 67, 1109 (1989). 